\title{
TARBAWI
}

Volume 3 No.1, Januari - Juni 2018

ISSN : 2527-4082

\section{Peranan Guru Pendidikan Agama Islam Dalam Mengatasi Perilaku Menyimpang Siswa}

The Role of Islamic Education Teachers in Mitigation Student Deviant Behavior

Mumtahanah

Sekolah Tinggi Agama Islam DDI Maros

\begin{abstract}
Abstrak
Penelitian ini menggunakan pendekatan kualitatif, sehingga yang menjadi instrumen utama dalam penelitian ini adalah peneliti itu sendiri. Adapun instrumen yang penulis gunakan dalam mengumpulkan data di lapangan sesuai dengan obyek pembahasan dalam penelitian ini adalah penulis melakukan observasi, interview, dan dokumentasi. Guru memiliki sebagian tanggung jawab orang tua untuk memberikan pendidikan, ketika anak dilimpahkan kepada guru di sekolah. Tidak peduli anak dari keluarga mana yang dilimpahkan. Guru adalah orang tua siswa di sekolah. Sebagai orang tua disekolah memang seharusnya guru bertanggung jawab terhadap perkembangan siswanya baik dari segi kognitif, afektif dan psikomotorik. Terlebih bagi Guru Pendidikan Agama Islam (PAI) yang memiliki tugas untuk tidak sekedar mentransfer pengetahuan saja namun juga berperan memberikan pengajaran dan bimbingan berkaitan dengan akhlak siswa. Berkaitan dengan ahklak atau contoh yang baik, maka Allah SWT telah memberikan gambaran mengenai ahklak Nabi Muhammad SAW. Karena dalam kehidupan, seorang manusia sejak lahir selalu berbuat dan bertindak, berfikir, berperasaan, merasa dan berhubungan dengan orang lain.
\end{abstract}

Kata Kunci: Pendidikan Agama Islam, Perilaku Menyimpang 


\begin{abstract}
This study uses a qualitative approach, so that the main instrument in this study is the researchers themselves. The instruments that the authors use in collecting data in the field in accordance with the object of discussion in this study is the authors make observations, interviews, and documentation. Teachers have some parental responsibility to provide education, when children are bestowed to teachers at school. No matter which child of the family is bestowed. Teachers are parents of students at school. As a parent in school, teachers should be responsible for the development of their students in terms of cognitive, affective and psychomotor. Especially for Islamic Religious Education Teachers (PAI) who have the task to not just transfer knowledge but also play a role to provide teaching and guidance related to morality students. Relating to ahklak or a good example, then Allah SWT has given a picture of the Prophet Muhammad's ahklak. Because in life, a human from birth always acts and acts, thinks, feels, feels and relates to others.
\end{abstract}

\title{
Keywords: Islamic Religious Education, Deviant Behavior
}

PENDAHULUAN

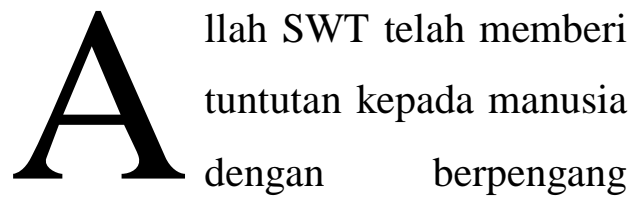

teguh pada agama Allah SWT, agama

Islam. Agama Islam memberi berbagai

petunjuk tentang hidup dan kehidupan

manusia. Namun hal itu baru dapat dipahami, diyakini, dihayati dan diamalkan setelah melalui tahap pendidikan. Nabi Muhammad Saw diutus ke dunia oleh Allah SWT sebagai pendidik manusia sehingga tidak diragukan lagi bahwa ajaran agama Islam sarat dengan konsep-konsep pendidikan, yang karena itu tidak salah jika Islam dijadikan sebagai alternatif strategi paradigma ilmu pendidikan dalam menjawab tantangan zaman yang semakin kompleks.

Islam merupakan alternatif strategis paradigma pendidikan, di samping pendidikan sebagai ilmu humaniora yang termasuk ilmu normatif, juga dapat dijadikan tolak ukur dalam menyikapi masalah pendidikan sekarang dalam menjalani kehidupan berbangsa dan bernegara Indonesia. Islam sebagai agama yang sarat dengan nilai-nilai ternyata sangat memungkinkan dijadikan sudut pandang dalam menganalisis persoalan-persoalan yang berkaitan dengan gejala-gejala pendidikan. Kerangka semacam inilah Islam sebagai agama dapat menjadi 
paradigma pengembangan fitrah yang dikaitkan dengan tugas dan fungsi manusia di muka bumi ini.

Manusia membutuhkan pendidikan dalam kehidupannya. Pendidikan merupakan usaha agar manusia dapat mengembangkan potensinya melalui proses pembelajaran. Sesuai dengan Undang-undang Sisdiknas (sistem Pendidikan Nasional) Nomor 20 Tahun 2003 Bab II Pasal 2 disebutkan bahwa Pendidikan Nasional berfungsi mengembangkan kemampuan dan membentuk watak serta peradaban bangsa yang bermartabat dalam rangka mencerdaskan kehidupan bangsa bertujuan untuk beriman dan bertaqwa kepada Tuhan Yang Maha Esa, berakhlak mulia, sehat, berilmu, cakap, kreatif dan menjadi warga yang demokratis serta bertanggung jawab.

Maka dari itu kegiatan belajar hendaknya menjadi prioritas untuk melihat ke depan yakni belajar untuk mengantisipasi realitas, ini makin menjadi penting bagi anak dan remaja yang hidup dalam era globalisasi yang menuntut keterbukaan dan kelenturan dalam pemikiran serta kemampuan memecahkan masalah-masalah nonrutin secara kreatif dan kritis.

Oleh sebab itu, dibutuhkan keterampilan- keterampilan tertentu yang menyiapkan peserta didik untuk dapat bersaing pada tingkat nasional dan internasional dalam pengembangan ilmu pengetahuan, teknologi dan ekonomi. Yang tidak kalah pentingnya ialah pendidikan humaniora dan pendidikan nilai. Terutama pada anak atau peserta didik yang sedang mengalami masa pertumbuhan dan perkembangan baik secara fisik maupun psikisnya, dimana pada masa-masa yang seperti itu seorang anak akan mengalami banyak perubahan sikap dan perilaku yang pada umumnya mengalami gejolak untuk melakukan sesuatu yang baru, sebagai bentuk rasa ingin tahu atau sekedar coba-coba dan seorang anak seusia remaja cendurung ingin melakukan halhal berbau negatif.

Sehingga perlu adanya kontrol dari berbagai pihak, baik itu dari pihak keluarga, masyarakat dan pihak sekolah. Dan sebagai pihak yang berperan penting dalam membina dan mengarahkan anak untuk dapat mengontrol ketidakstabilan emosi 
seorang anak didik adalah para pendidik yang ada di sekolah-sekolah dengan memberikan nasehat-nasehat serta saran kepada peserta didik yang mengalami gejolak untuk membantu dalam merubah sikap dan tingkah lakunya.

Guru memiliki sebagian tanggung jawab orang tua untuk memberikan pendidikan, ketika anak dilimpahkan kepada guru di sekolah. Tidak peduli anak dari keluarga mana yang dilimpahkan. Guru adalah orang tua siswa di sekolah. Sebagai orang tua disekolah memang seharusnya guru bertanggung jawab terhadap perkembangan siswanya baik dari segi kognitif, afektif dan psikomotorik.

Bimbingan terhadap siswa yang dilakukan oleh guru Pendidikan Agama Islam (PAI) tidaklah mengambil wewenang guru Bimbing Konseling (BK). Karena setiap guru berperan dalam proses pembelajaran sesuai dengan mata pelajaran yang diampunya. Hal ini pula yang menjadi dasar penulis untuk melakukan penelitian di sekolah MTsN Turikale Kabupaten Maros dengan judul, "Peranan Guru Pendidikan Agama Islam Dalam
Mengatasi Perilaku Menyimpang Siswa Di MTs Turikale Kabupaten Maros".

\section{METODE PENELITIAN}

Penelitian ini menggunakan pendekatan kualitatif, sehingga yang menjadi instrumen utama dalam penelitian ini adalah peneliti itu sendiri. Adapun instrumen yang penulis gunakan dalam mengumpulkan data di lapangan sesuai dengan obyek pembahasan dalam penelitian ini adalah penulis melakukan observasi, interview, dan dokumentasi.

1. Observasi

Dalam melakukan observasi perlu mempergunakan panca indera secara keseluruhan, sehingga dapat menjiwai obyek penelitian. Observasi terbagi dua bahagia yaitu observasi langsung dan observasi tidak langsung.

2. Interview/wawancara

Dalam melaksanakan interview perlu dilakukan secara langsung antara penyelidik dengan informan sehingga dapat lebih terbuka dalam berkomunikasi dalam rangka mendapatkan data yang jelas dan 
kongkrit. Adapun dari segi maka bangsa ini akan menjadi bangsa tujuannya, inteview dapat yang terbelakang, jauh tertinggal dari digolongkan ke dalam dua bagian yaitu : Interview Survey dan Diagnosis

3. Dokumentasi

Dokumentasi berasal dari kata dokumen yang berarti surat yang tertulis atau tercetak yang dapat dijadikan keterangan. Jadi dokumentasi adalah pemilihan atau pengumpulan bukti-bukti dan keterangan. Jadi dokumentasi merupakan buktibukti tertulis dalam hubungan dengan data dalam penelitian ini.

\section{PEMBAHASAN}

A. Gambaran Perilaku Menyimpang Yang Ditunjukkan Oleh Siswa Di MTs Negeri Turikale Kabupaten

\section{Maros}

Pada saat ini bangsa Indonesia telah dihadapkan dengan berbagai permasalahan yang sangat kompleks baik secara internal maupun eksternal, dapat kita bayangkan seandainya bangsa ini dipimpin oleh generasi muda atau anak bangsa yang bodoh, malas, tidak bermoral, dan sifat yang tidak terpuji, negara-negara lainnya.

Anak didik dipandang sebagai generasi yang belum matang dan dewasa, untuk itu perlu dibina dan dididik secara mental sehingga watak anak didik dapat berkembang dengan baik. Kenyataan saat ini menunjukkan betapa banyaknya para siswa yang terlibat dalam tingkah laku menyimpang. Watak siswa dan siswi saat ini sangat berbeda dengan generasi muda sebelumnya, umumnya generasi sekarang bersifat santai, kurang mandiri, kurang ulet, bersifat lebih mudah terpengaruh, emosional serta kurangnya rasa nasionalisme, hal ini dapat kita lihat dari kecendrungan setiap hari baik pelajar maupun pemuda yang kerap melakukan kebrutalan.

Tingkah laku seseorang dapat dikatakan menyimpang bilamana tingkah laku tersebut dapat merugikan dirinya sendiri maupun orang lain dan juga melanggar aturan-aturan, nilainilai, dan norma-norma, baik norma agama, norma hukum, norma adat. Tingkah laku menyimpang dapat terjadi dimana-mana, dan kapan saja, baik di 
sekolah, dalam keluarga maupun dalam kehidupan di masyarakat.

Jika kita membaca dan mendengar berita dari berbagai media masa baik cetak maupun elektronik, tidak jarang kita dengar dan lihat berbagai macam kasus kekerasan yang dilakukan oleh siswa atau siswi terhadap sesamanya, masyarakat sekitar, orang tua dan bahkan gurunya sendiri. Dan selanjutnya penulis akan menguraikan keadaan atau gambaran perilaku menyimpang yang ditunjukkan oleh siswa MTsN Turikale yang diperoleh dari hasil observasi atau pengamatan dan didukung oleh hasil wawancara penulis dengan narasumber penelitian.

\section{Sering Datang Terlambat.}

Siswa yang datang terlambat ke sekolah hampir menjadi pandangan umum dan keterlambatan mereka ini tentu mengganggu proses belajar di kelas. Dimana kehadirannya mengganggu proses belajar yang sedang berlangsung sehingga konsentrasi siswa yang lain bahkan guru dalam kelas bisa jadi terganggu. Seorang pelajar dalam mengikuti kegiatan belajar di sekolah tidak akan lepas dari berbagai peraturan dan tata tertib yang diberlakukan sekolah.

Keterlambatan pada siswa tersebut bukan berarti tanpa sebab, berbagai macam alasan diungkapkan para siswa yang sering terlambat, diantaranya adalah siswa yang tinggal jauh dari sekolah, masalah transportasi, bangun kesiangan dan sebagainya. Alasan-alasan seperti inilah yang sering dikemukakan siswa ketika datang terlambat pada saat jam pelajaran pertama sudah dimulai. Namun, apapun alasan para siswa yang datang terlambat menunjukkan tingkat kedisiplinan yang masih rendah. Dan tentunya hal ini tidak boleh dibiarkan begitu saja sehingga pada akhirnya akan menjadi budaya yang tidak baik pada lembaga pendidikan yang bersangkutan.

Adapun hasil wawancara penulis dengan Ibu DR. Hj. Nurbaeti M.Pd selaku kepala Madrasah Tsanawiyah Negeri Turikale terkait seringnya siswa datang terlambat ke sekolah, Beliau mengatakan bahwa:

$\begin{array}{lrrr}\text { "Hampir } & \text { semua } & \text { guru menemui } \\ \text { kondisi } & \text { dimana } & \text { siswa r sering } \\ \text { terlambat } & \text { sampai } & \text { di } & \text { sekolah atau }\end{array}$


masuk kelas. Meskipun peraturan dan tata tertib sekolah telah memuat tentang siswa terlambat dan sanksinya, namun masih saja ada siswa yang melanggar peraturan tersebut".

\section{Bolos Sekolah.}

Pergi ke sekolah bagi pelajar merupakan suatu hak sekaligus kewajiban sebagai sarana mengenyam pendidikan dalam rangka meningkatkan kehidupan yang lebih baik. Namun kenyataannya masih ada siswa MTsN Turikale yang enggan melakukannya tanpa alasan yang dapat dipertanggungjawabkan hingga pada yang akhirnya membolos.

Perilaku ini dilakukan dengan cara, siswa tetap pergi dari rumah pada pagi hari dengan berseragam, tetapi mereka tidak berada di sekolah. Perilaku ini umumnya ditemukan pada remaja mulai tingkat pendidikan MTs atau SMP. Memang cerita bolos sewaktu pelajaran sudah tidak asing lagi bagi sebagian kalangan murid ataupun masyarakat. Bolos atau meninggalkan jam pelajaran saat kegiatan belajar mengajar sedang berlangsung di sekolah, itu merupakan hal yang sering dilakukan oleh para pelajar.
Mereka lebih memilih untuk meninggalkan kelas daripada harus mendengarkan penjelasan guru yang tidak mereka mengerti. Mungkin masalah yang seperti ini sering dianggap sepele oleh sebagian kalangan, namun hal ini sangatlah disayangkan terutama bagi pemerintah yang sudah berusaha keras untuk memajukan pendidikan di Indonesia.

" Berdasarkan informasi yang kami terima baik dari pihak guru, siswa dan masyarakat sekitar sekolah bahwa ada beberapa anak didik kami yang sering tidak masuk sekolah, padahal mereka memakai pakaian seragam sekolah dan kebanyakan dari mereka adalah siswa yang sudah kelas III, sehingga mereka memperlihatkan contoh yang tidak baik kepada adik kelas mereka. Jadi kebiasaan bolos cukup memprihatinkan di kalangan pelajar karena bolos merupakan penyakit turunan dari kakak kelas atau senior mereka sendiri, namun kami dari pihak sekolah akan memberikan sanksi kepada mereka yang kedapatan bolos".

3. Sering Keluar Masuk Kelas Pada Saat Proses Pembelajaran Berlangsung.

Pada saat penulis melakukan observasi di MTsN Turikale Kabupaten Maros, penulis sering menjumpai siswa yang sering keluar masuk kelas, siswa ini sering kali meminta izin ke kamar mandi ketika proses pembelajaran 
berlangsung. Kemungkinan siswa yang seperti ini mengalami gangguan kesehatan yang mengharuskan sebentarsebentar harus ke kamar mandi. Namun ada pula siswa yang keluar masuk kelas dalam keadaan sehat.

Kejadian yang seperti ini terjadi karena siswa tersebut sudah mulai bosan di dalam kelas. Selain itu bisa juga karena temannya yang dilain kelas sudah menunggu di luar untuk mengajak nongkrong. Kejadian seperti ini menjadi masalah karena mengganggu jalannya pembelajaran apalagi ketika guru mengadakan kerja kelompok.

\section{Bullying (intimidasi) Kakak Kelas.}

Bully atau pelaku bullying adalah seseorang yang secara langsung melakukan agresi baik fisik, verbal atau psikologis kepada orang lain dengan tujuan untuk menunjukkan kekuatan atau mendemonstrasikan pada orang lain. Kebanyakan perilaku bullying berkembang dari berbagai faktor lingkungan yang kompleks.

Pihak sekolah sering mengabaikan keberadaan bullying ini, anak-anak sebagai pelaku bullying akan mendapatkan penguatan terhadap perilaku mereka untuk melakukan intimidasi anak-anak yang lainnya. Bullying berkembang dengan pesat dalam lingkungan sekolah yang sering memberikan masukan yang negatif pada siswanya misalnya, berupa hukuman yang tidak membangun sehingga tidak mengembangkan rasa menghargai dan menghormati antar sesama anggota sekolah.

\section{Tidak Sopan dan Berkata Kotor}

Sopan santun adalah sikap perilaku seseorang yang merupakan kebiasaan yang disepakati dan diterima dalam lingkungan pergaulan. Bagi siswa, sopan santun merupakan wujud budi pekerti luhur yang diperoleh melalui pendidikan dan latihan dari berbagai orang dalam kedudukan masing-masing, seperti orang tua dan guru, para pemuka agama dan masyarakat dan tulisan-tulisan atau hasil karya para bijak (cerdik pandai) yang merupakan bagian dari ajaran moral. Dari pendidikan dan latihan tersebut, diharapkan siswa dapat mewujudkannya 
dalam sikap bentuk dan perilaku yang selaras dan serasi dengan kodrat, tempat, waktu dan kondisi lingkungan dimana siswa berada sehari-hari.

\section{B. Faktor-faktor}

\section{Menyebabkan}

Perilaku Menyimpang Pada Siswa MTSN Turikale

\section{Kabupaten Maros}

Masa remaja dikatakan sebagai suatu masa yang berbahaya karena pada periode itu seseorang meninggalkan tahap kehidupan anak-anak untuk menuju ketahap selanjutnya yaitu tahap kedewasaan. Masa ini dirasakan sebagai suatu krisis karena belum adanya pegangan sedangkan kepribadiannya sedang mengalami pembentukan, pada waktu itu dia memerlukan bimbingan terutama dari orang tua di rumah dan guru di sekolah.

Anak yang menginjak masa remaja sudah sewajarnya menuntut banyak perhatian para orang tua. Mereka tentu saja sudah sadar diri dan oleh karenanya mudah mengundang perhatian kepada diri mereka sendiri walaupun seringkali mengatakan tidak menginginkan perhatian semacam itu. Perkembangan zaman yang telah maju dengan pesat telah mengubah gaya hidup remaja sekarang, dari kebiasaan mereka, minat mereka, bahasa dan pakaian yang mereka gunakan, politik dan musik yang mereka sukai, juga perkembangan seksualitas mereka. Bahkan sudah lazim bahwa keprihatinan orang tua terhadap kaum remaja sering kali tidak disambut baik oleh mereka, dianggap ikut campur dan mengakibatkan pembangkangan dari para pria dan wanita muda yang cemas dan berniat meraih kebebasan yang makin besar ini.

Apalagi dengan kemajuan ilmu dan teknologi saat ini yang maju begitu pesat dan sudah merambah kedalam kehidupan masyarakat kalangan atas maupun masyarakat kalangan bawah. Hal ini ditandai dengan adanya kemajuan teknologi komunikasi. Sehingga mempengaruhi perilaku dan gaya hidup mereka terutama para remaja yang sedang dalam masa transisi.

Pada zaman yang sudah semakin maju seperti ini, remaja dapat menggunakan teknologi apa saja yang 
dapat menyalurkan kepentingnnya, sehingga kadang dalam menggunakannya yang tanpa batas membuat mereka bertindak tidak sesuai dengan umurnya, maka munculah perilaku-perilaku yang tidak sesuai dengan norma yang ada dalam masyarakat sehingga melanggar hukum yang ada dalam masyarakat.

Perilaku menyimpang adalah perilaku yang tidak sesuai dengan nilainilai kesusilaan atau kepatutan yang ada di dalam masyarakat. Setiap individu memiliki latar belakang yang berbedabeda sehingga menghasilkan perilaku yang berbeda pula. Perilaku menyimpang menunjukkan bahwa proses sosialisasi telah gagal dilakukan. Ada beberapa faktor penyebab perilaku menyimpang yang penulis temukan pada siswa MTsN Turikale Kabupaten Maros yang merupakan hasil dari kuesioner atau angket yang penulis bagikan kepada 34 orang yang menjadi sampel penelitian ini. Di bawah ini penulis menguraikan dalam bentuk tabel mengenai persepsi siswa terkait faktorfaktor penyebab terjadinya perilaku menyimpang pada siswa MTsN Turikale.
1. Kurangnya perhatian dan kasih sayang orangtua

Keluarga merupakan unit sosial terkecil yang memberikan fondasi primer bagi perkembangan anak, keadaan lingkungan keluarga yang menjadi sebab timbulnya kenakalan remaja seperti keluarga yang brokenhome, rumah tangga yang berantakan disebabkan oleh kematian ayah atau ibunya, keluarga yang diliputi konflik keras, semua itu merupakan sumber yang subur untuk memunculkan kenakalan remaja dan dapat menimbulkan perilaku yang menyimpang pada siswa. Dari perilaku menyimpang di poin pertama ini, dapat diketahui bahwa dari 28 responden yang menjadi sampel dalam penelitan ini, terdapat 20 responden atau dengan nilai persentase $72 \%$ yang memilih kategori jawaban nomor 1 bahwa kurangnya perhatian dari keluarga dapat menimbulkan perilaku menyimpang atau kenakalan pada remaja. Dan untuk kategori jawaban kurang berpengaruh dipilih sebanyak 6 responden dengan nilai persentase $21 \%$, sedangkan untuk kategori jawaban kurangnya perhatian keluarga tidak mempengaruhi atau tidak 
menyebabkan kenakalan remaja yaitu dipilih ole 2 respoden dengan nilai persentase $7 \%$.

2. Pengaruh pergaulan dan teman yang nakal

Pengaruh budaya barat serta pergaulan dengan teman sebayanya yang sering mempengaruhinya untuk mencoba dan akhirnya malah terjerumus ke dalamnya Lingkungan adalah faktor yang paling mempengaruhi perilaku dan watak remaja. Jika dia hidup dan berkembang di lingkungan yang buruk, moralnya pun akan seperti itu adanya. Sebaliknya jika ia berada di lingkungan yang baik maka ia akan menjadi baik pula. Di dalam kehidupan bermasyarakat, remaja sering melakukan keonaran dan mengganggu ketentraman masyarakat karena terpengaruh dengan budaya barat atau pergaulan dengan teman sebayanya yang sering mempengaruhi untuk mencoba. Sebagaimana diketahui bahwa para remaja umumnya sangat senang dengan gaya hidup yang baru tanpa melihat faktor negatifnya, karena anggapan ketinggalan zaman jika tidak mengikutinya. Di poin kedua ini, dapat diketahui bahwa dari 28 responden yang ada di MTsN Turikale Kabupaten Maros terdapat 21 responden atau dengan nilai persentase $75 \%$ yang memilih kategori jawaban yang pertama atau pengaruh pergaulan dengan teman sebaya yang nakal merupakan salah satu faktor yang dapat menyebabkan terjadinya perilaku menyimpang pada remaja sedangkan untuk kategori pengaruh teman sebayah kurang mempengaruhi dipilih oleh sebanyak 7 responden atau dengan nilai persentase $25 \%$. Kemudian untuk kategori jawaban yang ketiga tidak ada responden yang memilihnya atau $0 \%$.

3. Pengaruh media seperti televisi dan internet

Televisi yang menampilkan acara-acara dan iklan bisa sangat mempengaruhi kejiwaan dan gaya hidup serta perilaku siswa yang menontonnya. Pendidikan yang merupakan hal yang sangat penting untuk membentuk perilaku, sering mengunakan media massa sebagai alat penyampai, penghubung, dan perantara yang dipandang sangat efektif dan efisien.

Salah satu media massa atau media komunikasi dan informasi adalah 
televisi dan internet. Kemampuan media dalam mengubah dan membentuk perilaku sangat besar dan tidak diragukan lagi. Suguhan acara-acara telivisi mampu menyihir dan mampu mendoktrin jutaan manusia yang menyaksikannya. Tanpa keberadaan media dalam kehidupan manusia, manusia selalu merasa ketinggalan segalanya, sehingga manusia memposisikan media elektronik seperti televisi dan internet sebagai kebutuhan pokok dalam kehidupan, agar dapat bertahan dalam kehidupan. Dari pengaruh media ini, dapat diketahui bahwa dari 28 responden yang menjadi sampel dalam penelitian ini di MTsN Turikale Kabupaten Maros terkait pengaruh media elektronik berupa televisi dan internet dapat menimbulkan kenakalan remaja dan penyimpangan perilaku dipilih oleh sebanyak 25 responden dengan nilai persentase $89 \%$. Sedangkan yang memilih kurang berpengaruh dipilih oleh sebanyak 3 responden dengan nilai persentase $11 \%$. Dan untuk kategori jawaban tidak berpengaruh yaitu tidak ada responden yang memilihnya atau $0 \%$.
4. Keadaan ekonomi yang buruk.

Keadaan ekonomi setiap orang itu berbeda-beda dan bertingkat, ada yang keadaan ekonominya tinggi, sedang, dan rendah. Keadaan ekonomi yang rendah atau buruk dalam suatu keluarga, dapat menimbulkan broken home dan juga merupakan hambatan bagi perkembangan kepribadian remaja.hal ini disebabkan orangtuanya sibuk memenuhi kebutuhan dalam rumah tangga sehingga pendidikan anak menjadi terlantar.

Di samping itu anak usia remaja biasanya mempunyai keinginankeinginan, keindahan-keindahan dan penuh dengan cita-cita, mereka menginginkan berbagai macam mode pakaian, hiburan, kendaraan dan sebagainya. Apabila orangtua tidak dapat memenuhi kebutuhan dan keinginannya itu, maka akan remaja akan merasa tertekan kemudian timbullah khayalan-khayalan kalau memiliki harta yang banyak seperti halnya teman-temannya. Dan karena orangtuanya tidak dapat memenuhi keinginannya, mungkin ia akan berusaha memperolehnya dengan jalan 
mencuri, merampas, memalak, dan sebagainya.

Dari data tersebut, dapat diketahui bahwa dari 28 responden yang menjadi sampel dalam penelitian ini terdapat dua kategori jawaban yang berbeda yaitu keadaan ekonomi yang buruk dapat berpengaruh dan kurang berpengaruh dalam penyimpangan perilaku namun memiliki frekuensi serta persentase yang sama yaitu 12 dengan nilai persentase $43 \%$. Dan untuk kategori jawaban keadaan ekonomi keluarga yang buruk tidak berpengaruh terhadap perilaku menyimpang siswa dipilih oleh 4 responden dengan nilai persentase $14 \%$.

5. Minimnya pemahaman agama

Pemahaman tentang agama sebaiknya dilakukan semenjak kecil, yaitu melalui kedua orang tua dengan cara memberikan pembinaan moral dan bimbingan tentang keagamaan, agar nantinya setelah mereka remaja bisa memilah baik buruk perbuatan yang ingin mereka lakukan sesuatu di setiap harinya. Kondisi masyarakat sekarang yang sudah begitu mengagungkan ilmu pengetahuan mengakibatkan kaidahkaidah moral dan tata susila yang dipegang teguh oleh orang-orang dahulu menjadi tertinggal di belakang.

Dalam masyarakat yang telah terlalu jauh dari agama, kemerosotan moral orang dewasa sudah lumrah terjadi. Kemerosotan moral, tingkah laku dan perbuatan-perbuatan orang dewasa yang tidak baik menjadi contoh atau tauladan bagi anak-anak dan remaja sehingga berdampak timbulnya kenakalan remaja dan perilaku menyimpang pada siswa. Dari data tersebut, dapat diketahui bahwa dari 28 responden yang menjadi sampel dalam penelitian ini terkait dengan pemahaman agama yang minim menjadi salah satu faktor penyebab timbulnya penyimpangan perilaku pada remaja. Maka terdapat 20 responden atau dengan nilai persentase $71 \%$ yang memilih kategori jawaban berpengaruh sedangkan yang memilih kategori jawaban kurang berpengaruh sebanyak 5 responden dengan nilai persentase 18 $\%$. Dan untuk kategori jawaban yang ketiga yaitu minimnya pemahaman agama tidak berpengaruh dipilih sebanyak 3 responden dengan persentase $11 \%$. 


\section{Peranan Guru Pendidikan Agama Islam Dalam Mengatasi Perilaku Menyimpang Siswa Di MTs Negeri Turikale Kabupaten Maros}

Di bawah ini merupakan peranan yang dilakukan oleh guru Pendidikan Agama Islam dalam mengatasi perilaku menyimpang siswa MTsN Turikale Kabupaten Maros yang diperoleh dari hasil wawancara, baik itu kutipan wawancara langsung maupun kutipan hasil wawancara secara tidak langsung.

\section{Tindakan Preventif (Pencegahan)}

Tindakan preventif adalah tindakan yang dilakukan oleh guru Pendidikan Agama Islam untuk mencegah atau mengantisipasi agar perilaku menyimpang tidak tumbuh dan berkembang sehingga tidak memengaruhi peserta didik lainnya. Adapun cara preventif yang dilakukan oleh guru Pendidikan Agama Islam dalam mengatasi perilaku menyimpang adalah sebagai berikut:

a. Melaksanakan salat zuhur berjamaah

Pelaksanaan salat zuhur berjamaah di sekolah bertujuan agar nilai-nilai spiritual agama mampu menyentuh lubuk hati peserta didik. Dengan begitu, diharapkan nilainilai agama tertanam di dalam dirinya sehingga mampu menjadi tameng buat siswa sehingga mampu mencegah diri dari perbuatan perilaku menyimpang.

b. Melaksanakan kultum

Guru Pendidikan Agama Islam dalam mengatasi dan menanggulangi perilaku menyimpang siswa adalah melaksanakan kultum. Hal ini dilaksanakan dua kali dalam sepekan. Pengaturan pelasanaannya diserahkan kepada pengurus OSIS dan pengurus OSIS inilah yang menunjuk personil atau panitia pelaksana kegiatan seperti siapa yang bertindak sebagai protokol, yang bertindak sebagai pembawa kultum.

c. Peringatan hari hari besar Islam Peringatan hari-hari besar Islam seperti tahun baru Islam, peringatan Maulid, dan peringatan Isra' Mi'raj rutin dilaksanakan di MTsN Turikale Maros. 


\section{Tindakan Represif.}

Tindakan represif adalah tindakan yang dilakukan oleh guru Pendidikan Agama Islam untuk menahan perilaku menyimpang agar tidak lebih parah. Adapun cara represif yang dilakukan oleh guru Pendidikan Agama Islam dalam berkontribusi menanggulangi perilaku menyimpang adalah sebagai berikut:

\section{a. Bimbingan dan Nasehat}

Tugas dan tanggung jawab guru di sekolah senantiasa dituntut untuk memahami kondisi siswanya agar tidak serta merta memvonis atas berbagai tingkah laku yang terjadi. siswa yang melakukan pelanggaran tidak serta merta langsung diberi sanksi, akan tetapi guru Pendidikan Agama Islam berupaya mengetahui terlebih dahulu penyebab mengapa siswa melakukan perilaku tersebut. Setelah penyebab munculnya perilaku tersebut, sedapat mungkin dapat diberikan solusi yang tepat agar peserta didik mampu mengakhiri perilaku menyimpang yang sering dilakukan.

b. Menegakkan disiplin sekolah
Peraturan tata tertib sekolah dibuat untuk menegakkan disiplin, baik itu untuk pendidik maupun siswa. Dengan peraturan tata tertib tersebut, diharapkan adanya stabilitas kenyamanan bersama supaya tidak terjadi kesemrawutan dalam menangani berbagai persoalan yang terjadi.

c. Penerapan sanksi

Perilaku menyimpang yang berulang-ulang kali terjadi setelah berbagai upaya dilakukan untuk mencegah namun ternyata terjadi lagi maka guru melakukan tindakan berupa penerapan sanksi, tentunya dengan tujuan memberi efek jera kepada pelaku perilaku menyimpang tersebut.

d. Pemanggilan Orang Tua

Peserta didik setelah dijatuhkan sanksi namun masih sering melakukan perilaku menyimpang, maka langkah selanjutnya adalah pemanggilan orang tua. Hal ini dilakukan sebagai wujud kerjasama pihak sekolah dan orang tua di rumah 


\section{Tindakan Kuratif}

Tindakan kuratif merupakan tindakan untuk merehabilitasi peserta didik dari perilaku menyimpang. Tindakan ini merupakan tindakan terakhir dalam mengatasi berbagai permasalahan siswa. Hal ini dilakukan agar perilaku menyimpang tersebut tidak menjangkiti peserta didik lainnya. Adapun tindakan kuratif yang dilakukan pihak sekolah kepada siswa yaitu skorsing dan pengembalian siswa kepada orang tua.

\section{Skorsing}

Skorsing merupakan tindakan penghentian bersekolah sementara kepada siswa bertujuan untuk merenungi kembali segala perilaku yang dilakukan. Dengan skorsing ini, diharapkan bisa memulihkan kembali siswa untuk bersikap lebih baik lagi.

2. Pengembalian siswa kepada orang tua

Siswa setelah berbagai upaya dilakukan terhadapnya, ternyata belum menunjukkan perubahan dalam artian skorsing sudah $\begin{array}{lcr}\text { diterapkan } & \text { namun } & \text { belum } \\ \text { menunjukkan } & \text { sikap jera, } & \text { maka } \\ \text { langkah } & \text { terakhir } & \text { adalah }\end{array}$ mengembalikan siswa kepangkuan orang tua. Terkait dengan tindakan kuratif, maka penulis akan menampilkan hasil wawancara dengan Ibu Kepala Madrasah Tsanawiyah Negeri Turikale Maros, berikut kutipannya:

Adapun hasil wawancara penulis dengan guru akidah akhlak di MTsN Turikale terkait tindakan kuratif sebagai peranan guru dalam mengatasi perilaku menyimpang siswa, Beliau mengatakan bahwa:

"Saya selaku guru akidah akhlak di sekolah ini mempunyai tanggung jawab moril untuk pembentukan akhlak siswa, karena akhlak merupakan pondasi yang utama dalam pembentukan pribadi manusia yang seutuhnya. Dimana pendidikan mengarahkan siswa pada terbentuknya pribadi yang berakhlak, merupakan hal yang harus dilakukan oleh setiap pendidik. Dan tindakan kuratif merupakan tindakan terakhir dan suatu bentuk ketegasan dari sekolah bagi siswa yang tidak memiliki niat untuk memperbaiki atau merubah sikapnya". 


\section{PENUTUP}

Berdasarkan hasil analisa kuesioner dan observasi yang diperkuat dengan data hasil interview dan dokumentasi, serta didukung oleh beberapa referensi yang merupakan hasil penelitian dari orang lain, maka dapat ditarik kesimpulan sebagai berikut:

1. Gambaran perilaku menyimpang yang ditunjukkan oleh siswa di MTs Negeri Turikale Kabupaten Maros adalah sering datang terlambat ke sekolah, bolos sekolah, sering keluar masuk kelas pada saat proses pembelajaran berlangsung, bullying (intimidasi) kakak kelas, dan tidak sopan dan berkata kotor.

2. Faktor-faktor yang menyebabkan terjadinya perilaku menyimpang pada siswa MTSN Turikale Kabupaten Maros adalah kurangnya perhatian dan kasih sayang orangtua, pengaruh pergaulan dan teman yang nakal, pengaruh media seperti televisi dan internet, keadaan ekonomi yang buruk, dan minimnya pemahaman agama.
3. Peranan guru pendidikan agama Islam dalam mengatasi perilaku menyimpang siswa di MTs Negeri Turikale Kabupaten Maros adalah pertama, dengan tindakan preventif (pencegahan), dengan cara mewajibkan peserta didik melaksanakan salat zuhur, melaksanakan kultum, mengadakan peringatan hari-hari besar Islam, melakukan pendekatan untuk mengatasi masalah yang dihadapi siswa, dan menjalin kerjasama dengan orang tua siswa. Kedua, tindakan represif, dengan cara, bimbingan dan nasihat, menegakkan disiplin sekolah, penerapan sanksi dan p emanggilan orang tua. Ketiga, tindakan kuratif dengan cara skorsing dan pengembalian siswa kepada orang tua.

\section{DAFTAR PUSTAKA}

Abdul Malik dkk, Pengembangan Kepribadian Pendidikan Agama Islam, Jakarta: Direktorat Pendidikan Agama Islam, 2009.

Achamadi, Islam Sebagai Paradigma Ilmu pendidikan, Yogyakarta: Aditya Media, 1992. 
Ananda Santoso dkk, Kamus lengkap Bahasa Indonesia, CV. Cahaya Agensy, 2005.

Anton M. Moeliono, et.al, Kamus Besar Bahasa Indonesia, Cet. 2, Jakarta: Balai Pustaka, 1989.

Damsar, Pengantar Sosilogi Pendidikan, Jakarta: Kencana, 2011.

Departemen Agama RI, Al-Qur'an dan Terjemahannya, Bandung: Jumanatul Ali'-Art, 2004

Endang Poerwanti dan Nur Widodo, Perkembangan Peserta Didik, Malang: UMM Press, 2002.

Elfi Mu'awanah dkk, Bimbinga Konseling Islami Di Sekolah Dasar, Ed. 1, Cet. 3, Jakarta: Bumi Aksara, 2012.

Kunandar, Guru Profesional, Jakarta: PT Raja Grafindo Persada, 2010.

Muhibbin Syah, Psikologi Belajar, Edisi Revisi, Jakarta: PT. Raja Grafindo, 2008.

M. Amin Amirullah, Panduan Menyusun Proposal Penelitian Tesis dan Disertasi, Cet. I, Jakarta: Smart Pustaka, 2013.

Muhaimin, paradigma Pendidikan Islam, Bandung: PT Remaja Rosdakarya, 2002.

M. Sayyid Muhammad Az-Za'balawi, Pendidikan Remaja Antara Islam dan Ilmu Jiwa, Jakarta: Gema Insani Press, 2007

Pupuh Faturrohman dan Sobri Sutikno, Strategi Belajar Mengajar. Cet. I; Aditama, 2007.

Sugiono, Metode Penelitian Kuantitatif, Kualitatif dan Kombinasi, Bandung: Alfabeta, 2011.

Sudjana, Metode Statistik, Bandung, Tarsito, 1986.

Sumiati dan Asra, Metode Pembelajaran, Cet. I; wacana Prima, 2009.

Suparlan, Menjadi Guru Efektif, Cet. 1, Yogyakarta: Hikayat Publishing, 2005.

Syaiful Bahri Djamarah, Guru dan Anak Didik dalam Interaksi Edukatif, Jakarta: PT Rineka Cipta, 2005.

Undang-Undang RI, Guru dan Dosen Sisdiknas, Cet. I, Surabaya: Wacana Intelektual, 2009.

Winarto Surakhmat, Dasar dan Tehknik Research, Ed. VI, Bandung : Tarsito, 1987

Wjs. Poerwardaminta, Kamus Umum Bahasa Indonesia, Cet. VII, Jakarta: PN Balai Pustaka, 1985.

Zakiah Daradjat, ILmu Pendidikan Islam, Jakarta: PT Bumi Aksara, 2008 